\title{
Studies on the Allergenic Structure of Hen Ovomucoid by Chemical and Enzymic Fragmentation
}

\author{
Jun-ichi Kurisaki, Yoshiko Konishi, Shuichi Kaminogawa \\ and Kunio Yamauchi \\ Department of Agricultural Chemistry, Faculty of Agriculture, \\ The University of Tokyo, Bunkyo-ku,-Tokyo 113, Japan
}

Received August 26, 1980

\begin{abstract}
The allergenic structure of ovomucoid was studied by fragmentation with cyanogen bromide and Staphylococcal protease. Two fragments obtained by cyanogen bromide cleavage were identified in the primary structure of ovomucoid to be peptide $1 \sim 68$ and peptide $69 \sim 186$ cleaved at position 84 and linked together by a disulfide bridge between 70 and 109 .

Allergenic activity, assayed by a passive cutaneous anaphylaxis inhibition test using $\mathrm{IgE}$ antibody from mouse, was retained only in peptide $69 \sim 186$. Three fragments obtained by Staphylococcal protease digestion corresponded to peptide $1 \sim 130$ and two peptides $131 \sim 186$ differing in carbohydrate content. Only peptide $1 \sim 130$ was allergenic. The trypsin binding ability remained only in the allergenic peptides. These results suggest that either the common peptide portion in $1 \sim 130$ and $69 \sim 186$ or a long range structure composed of these peptides is essential for allergenic activity.
\end{abstract}

Hen's egg is a well known food which frequently causes atopic allergic reactions. However, only limited and divergent information is available on the allergenic components in egg which are responsible.

Perlman ${ }^{11}$ reported that ovalbumin frequently produced the intensive skin reactions by the skin test, which has been known to be a convenient method for the diagnosis of allergy and examination of the allergen. Campbell and co-workers ${ }^{2}$ demonstrated that lysozyme often caused the sensitization. Berrens and Bleumink $^{3)}$ proposed that the $\mathrm{N}$-glycosidic linkage in egg, as well as in various food allergens, could be responsible. Recently, Bleumink and Young ${ }^{4,5)}$ identified the allergen and finally concluded that the ovomucoid fraction possessed the skin reactive potency. We $\mathrm{e}^{6)}$ also conducted examinations to identify the allergens in egg by skin test and confirmed that ovomucoid was one of the strongest allergens.

The next important problem to be overcome following the identification of the allergen is to elucidate the allergenic structures. Already, in certain allergens such as antigen $\mathrm{E}$ in ragweed pollen, ${ }^{7 /}$ Group I in rye grass pollen ${ }^{8)}$ and allergen $M$ in codfish, ${ }^{9,10)}$ allergenic structures have been extensively studied. These studies should surely provide significant information for a way to achieve the immunotherapy of the allergy. Particularly in the case of food allergens, such as egg allergens, the reduction of allergenic activity, if possible, by a prescribed method of food processing would be preferable. Thus, the characterization of the allergenic structure of ovomucoid is required.

In this paper, we report a study on the preliminary localization of allergenic determinants in ovomucoid by the examination of allergenic activity of several peptide fragments from ovomucoid.

\section{MATERIALS AND METHODS}

Purification of ovomucoid. Hen's eggs from White Leghorn bred in the National Institute of Animal Industry, Chiba, Japan, were used within one day after laying. 
Ovomucoid was prepared according to the method of Fredericq and Deutsch. ${ }^{11)}$ Egg white was isolated, homogenized, and adjusted to $\mathrm{pH} 3.5$ with $1 \mathrm{~N} \mathrm{H}_{2} \mathrm{SO}_{4}$. An equal volume of $10 \%$ sodium trichloroacetate ( $\mathrm{pH} \mathrm{3.0)}$ was added and the mixture was allowed to stand overnight at $4^{\circ} \mathrm{C}$, then the precipitate was removed by centrifugation. The supernatant was adjusted to $\mathrm{pH} 6.0$ with $0.5 \mathrm{~N} \mathrm{NaOH}$ and twice a volume of precooled ethanol were added. After $4 \mathrm{hr}$ the precipitate was collected by centrifugation, dissolved in water, dialyzed against water and lyophilized. The purification of ovomucoid was carried out by affinity chromatography on trypsin-Sepharose $4 \mathrm{~B}$ according to the method of Beeley and Mccairns. ${ }^{12}$ Crude ovomucoid prepared by the method of Fredericq and Deutsch was dissolved in $0.1 \mathrm{~m}$ glycine- $\mathrm{NaOH}$ buffer containing $0.5 \mathrm{M}$ $\mathrm{NaCl}(\mathrm{pH} \mathrm{7.0)}$, and applied to a column of the trypsinSepharose $4 \mathrm{~B}$ equilibrated with the glycine buffer. Elution was performed initially with the glycine buffer $(\mathrm{pH} 7.0)$, and subsequently with $0.1 \mathrm{M}$ glycine- $\mathrm{HCl}$ buffer $(\mathrm{pH} 1.5)$ to dissociate ovomucoid from the immobilized trypsin. The flow rate was $40 \mathrm{ml} / \mathrm{hr}$. Fractions of $5 \mathrm{ml}$ were collected and monitored at $280 \mathrm{~nm}$ with a ISCO model UA-5 absorbance monitor. The purified ovomucoid was dialyzed against water, lyophilized and used for experiments.

Immunization and bleeding. It is preferable for the investigation of allergenic structure to utilize human $\mathrm{IgE}$ antibody specific for ovomucoid. However, because of the impossibility of obtaining the human antibody, we used $\mathrm{IgE}$ antibody from mouse.

Four-week-old mice of two strains were used for immunization to produce $\mathrm{IgE}$ antibodies. The two strains, $\mathrm{C} 3 \mathrm{H} / \mathrm{J}$ and $\mathrm{A} / \mathrm{He}$, have been known as a genetically high responder to ovomucoid. ${ }^{3)}$ Mice of each strain were injected with $1 \mu \mathrm{g}$ of ovomucoid in $0.2 \mathrm{ml}$ of saline with complete Freund's adjuvant intraperitoneally. Four days later, the mice were boosted intraperitoneally with $1 \mu \mathrm{g}$ of antigen in $0.2 \mathrm{ml}$ of saline together with alminum hydroxide gel. Booster injections were carried out on days 3,28 and 42 . Bleeding was performed 4 days after every immunization. Serum collected after centrifugation was stored at $-80^{\circ} \mathrm{C}$ until use.

Titration of IgE antibody and assay of allergenic activity. Titration of IgE antibodies in the serum was carried out by heterologous passive cutaneous anaphylaxis (PCA) assay in an SD rat described by Mota and Wong. ${ }^{14)}$ This is a useful method by which IgE antibody in mouse serum can be assayed within a few hours after sensitization. The sera obtained from mice were diluted five times and further serially two-fold. These sera were injected intracutaneously into the shaved backs of SD rats. Two hours later, $1.0 \mathrm{ml}$ of $1 \%$ Evans blue solution containing $3 \mathrm{mg}$ of ovomucoid was injected intravenously. The rats were sacrificed $20 \mathrm{~min}$ later and the lesions were measured. A blue spot with an average diameter of $5 \mathrm{~mm}$ or more was regarded as a positive reaction. Titer was expressed as the reciprocal of dilution. The test was set up in duplicate in different rats for each sample.

Allergenic activity of ovomucoid fragments was assessed with PCA inhibition test. The test utilized the PCA reaction to observe the neutralization of $\mathrm{IgE}$ antibody specific for allergen by the fragments. The antiserum was mixed with a sufficient amount of fragments and incubated at $25^{\circ} \mathrm{C}$ for $1 \mathrm{hr}$. The mixture was titrated as above to assay the residual IgE antibodies specific for ovomucoid. The untreated antiserum was also titrated in the same animal for the control. The neutralized antiserum failed to give a reaction.

Cleavage of ovomucoid with cyanogen bromide. Ovomucoid was cleaved by cyanogen bromide (CNBr) according to Beeley. ${ }^{15)} \mathrm{CNBr}(10 \mathrm{mg} / \mathrm{ml})$ and ovomucoid $(10 \mathrm{mg} / \mathrm{ml})$ were dissolved in $70 \%$ formic acid. The reaction was allowed to proceed under $\mathrm{N}_{2}$ at $25^{\circ} \mathrm{C}$ for $18 \mathrm{hr}$ in the dark.

The removal of $\mathrm{CNBr}$ and fractionation of the $\mathrm{CNBr}$ cleaved ovomucoid (CNBr-ovomucoid fragments) were carried out simultaneously by gel filtration. A column $(2.5 \times 90 \mathrm{~cm})$ of Bio-Gel P-10 (Bio-Rad Lab.) was equilibrated with $5 \%$ formic acid. Elution was performed at a flow rate of $4 \mathrm{ml} / \mathrm{hr}$.

Digestion of ovomucoid with Staphylococcal protease. Digestion of ovomucoid was performed according to the method of Kato et al. ${ }^{16)} 2 \%$ ovomucoid was incubated with Staphylococcus aureus V8 protease (Miles Lab., 1/33 $\mathrm{w} / \mathrm{w}$ ) in $0.1 \mathrm{M}$ ammonium bicarbonate $(\mathrm{pH} 8.0$ ) for $36 \mathrm{hr}$ at room temperature. Fragments of the digested ovomucoid with Staphylococcal protease (protease treated ovomucoid fragments) were fractionated by gel filtration on Bio-Gel P-10 as described in the fractionation of CNBrovomucoid fragments. Further, to remove the protease from each fraction, ion exchange chromatography was carried out on a DEAE-Sephacel column $(2.5 \mathrm{~cm} \times 20 \mathrm{~cm})$ in $0.05 \mathrm{M}$ Tris- $\mathrm{HCl}$ buffer $(\mathrm{pH} 8.0$ ) with a linear gradient of $\mathrm{NaCl}$ from zero to $0.4 \mathrm{M}$.

Estimation of affinity of ovomucoid fragments for trypsin. Affinity for trypsin of ovomucoid fragments was estimated on a trypsin-Sepharose 4B column. Equilibration and elution were carried out by the same method as in the preparation of ovomucoid.

Analytical methods. Amino acid analysis was performed after hydrolysis with $6 \mathrm{~N} \mathrm{HCl}$ at $110^{\circ} \mathrm{C}$ for $20 \mathrm{hr}$ and $72 \mathrm{hr}$ in a evacuated sealed tube. ${ }^{17}$ Analyses were made with a Hitachi model 835 amino acid analyzer.

$\mathrm{N}$-terminal residue was identified by the method of Gray $^{18}$ and dansyl derivatives of amino acids were identified with polyamide-thin layer chromatography according to the method of Woods and Wang. ${ }^{19)}$

Hexose was determined by the method of Dubois et al. ${ }^{20)}$ using a mixture of mannose and galactose $(4: 1)$ as 
standard. Sialic acid was measured by the method of Warren $^{21)}$ after hydrolysis with $0.1 \mathrm{~N}_{2} \mathrm{SO}_{4}$ at $80^{\circ} \mathrm{C}$ for $1 \mathrm{hr}$. $\mathrm{N}$-acetylneuraminic acid was used as standard. Glucosamine was determined by using an amino acid analyser after hydrolysis with $4 \mathrm{~N} \mathrm{HCl}$ for $6 \mathrm{hr}$ at $100^{\circ} \mathrm{C}$.

Electrophoresis. SDS-polyacrylamide gel electrophoresis was performed by the method of Weber and Osborn. ${ }^{22}$ The sample was dissolved in $0.1 \mathrm{M}$ phosphate buffer containing $1 \%$ SDS and 1\%2-mercaptoethanol and applied to the $7.5 \%$ gel. SDS-urea-polyacrylamide gel electrophoresis was performed in the $12.5 \%$ gel containing $8 \mathrm{M}$ urea according to the method of Swank and Munkres. ${ }^{23)}$ After electrophoresis, protein was stained by Coomassie Brilliant Blue.

\section{RESULTS}

\section{Characterization of CNBr-ovomucoid frag- ments}

The products of $\mathrm{CNBr}$ cleavage of ovomucoid gave three peaks on Bio-Gel P-10 as shown in Fig. 1A. The elution volume and electrophoretic pattern of the first peak (peak 0 ) were consistent with those of the intact ovomucoid. The next two peaks (Peaks 1 and 2) were purified by rechromatography and designated $\mathrm{Fc}-1$ and $\mathrm{Fc}-2$ respectively. $\mathrm{Fc}-1$ and Fc-2 exhibited a single band without 2mercaptoethanol in SDS-polyacrylamide gel electrophoresis as shown in Fig. 1B. However, in the presence of 2-mercaptoethanol, Fc-1 split off into two bands (Figure not shown). These results implied that Fc-1 was composed of two polypeptide chains linked by a disulfide bridge, while Fc-2 was a single. The molecular weights of $\mathrm{Fc}-1$ and $\mathrm{Fc}-2$ were estimated to be about 18,000 and 12,000 respectively by SDSpolyacrylamide gel electrophoresis.

The amino acid compositon and $\mathrm{N}$-terminal residue of each $\mathrm{CNBr}$-ovomucoid fragment are represented in Table I. Methionine was neither found in Fc-1 nor in Fc-2. This shows that ovomucoid was completely cleaved with $\mathrm{CNBr}$. The N-terminal of $\mathrm{Fc}-1$ was found to be asparagine or aspartic acid because of the detection of DNS-aspartic acid in Fc-1. In Fc2, alanine was found.

Elution profiles of $\mathrm{CNBr}$-ovomucoid fragments on trypsin-Sepharose $4 \mathrm{~B}$ are shown in Fig. 2. Only FC-1 maintained the binding

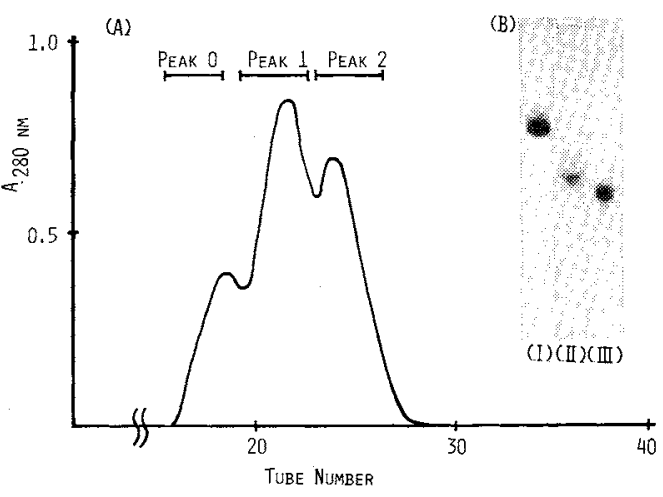

Fig. 1. Bio-Gel P-10 Column Chromatography of the Products Obtained by Cleavage of Ovomucoid with Cyanogen Bromide and SDS-Polyacrylamide Gel Electrophoretic Patterns of the Fragments after Rechromatography.

(A) The products were eluted with $5 \%$ formic acid at a flow rate of $4 \mathrm{ml} / \mathrm{hr} .3 \mathrm{ml}$ fractions were collected. The portions indicated by the bar were pooled. (B) Electrophoresis was carried out with a current of $8 \mathrm{~mA} /$ tube using $7.5 \%$ gel without 2 -mercaptoethanol. (I) peak 0; (II) Fc-1; (III) Fc-2.

Table I. Amino Acid Composition and N-Terminal Residues of the Fragments OBTAINED By Cyanogen Bromide Cleavage $(\mathrm{mol} \%)$

\begin{tabular}{lrrrr}
\hline & Fc-1 & $\begin{array}{r}\text { Peptide* } \\
69 \sim 186\end{array}$ & Fc-2 & $\begin{array}{c}\text { Peptide* } \\
1 \sim 68\end{array}$ \\
\hline Asp & 16.52 & 16.10 & 16.57 & 16.17 \\
Thr & 6.94 & 6.77 & 7.33 & 7.35 \\
Ser & 7.49 & 6.77 & 4.67 & 4.41 \\
Glu & 7.10 & 6.77 & 8.71 & 10.29 \\
Pro & 3.56 & 4.23 & 4.48 & 4.41 \\
Gly & 8.46 & 8.47 & 7.49 & 7.35 \\
Ala & 6.97 & 6.77 & 4.87 & 4.41 \\
Cys/2 & 10.33 & 10.16 & 9.02 & 8.82 \\
Val & 7.43 & 8.47 & 7.13 & 7.35 \\
Met & 0.00 & 0.84 & 0.00 & 1.47 \\
Ile & 0.00 & 0.00 & 5.09 & 4.41 \\
Leu & 6.19 & 5.93 & 6.16 & 5.88 \\
Tyr & 3.23 & 3.38 & 2.83 & 2.94 \\
Phe & 2.73 & 2.54 & 2.99 & 2.94 \\
Lys & 6.98 & 6.77 & 7.63 & 7.35 \\
His & 2.57 & 2.54 & 1.87 & 1.47 \\
Arg & 3.44 & 3.38 & 3.07 & 2.94 \\
N-Terminus & Asp or Asn & Asn & Ala & Ala \\
\hline - & & & & \\
\hline
\end{tabular}

* According to Kato et al. ${ }^{24)}$. 

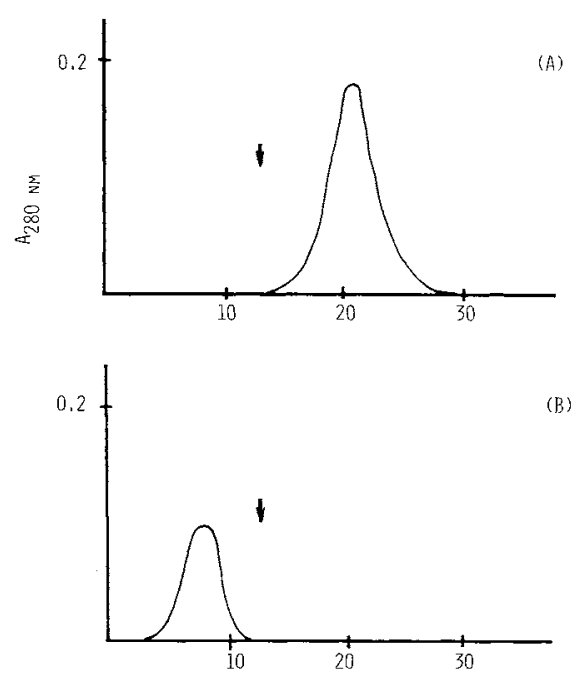

TUBE NUMBER

Frg. 2. Affinity Chromatography of the Fragments Obtained by Cleavage of Ovomucoid with Cyanogen Bromide on Trypsin-Sepharose 4B.

Elution was started with $0.1 \mathrm{M}$ glycine- $\mathrm{NaOH}$ buffer $(\mathrm{pH}$ 7.0) containing $0.5 \mathrm{M} \mathrm{NaCl}$ and subsequently the buffer was changed to $0.1 \mathrm{M}$ glycine- $\mathrm{HCl}(\mathrm{pH} 1.5)$ containing $0.5 \mathrm{M} \mathrm{NaCl}$ at the point indicated by the arrow. (A) Fc-1; (B) $\mathrm{Fc}-2$.

activity to trypsin.

\section{PCA inhibitory activity of CNBr-ovomucoid fragments}

Figure 3 and Table II show the results of PCA inhibition tests of CNBr-ovomucoid fragments. The mixture of antiserum and Fc-1 did not exhibit the blue spot even in an undiluted state; the titer of the mixture was zero. This clearly shows that the residual IgE antibodies in the mixture are below any detectable level. On the other hand, positive PCA reaction was induced by the mixture of antiserum and Fc-2. The titer of this mixture was estimated to be the same value $(320)$ as that of the control. Therefore Fc-1 was almost comparable to ovomucoid in binding activity to ovomucoid-specific antibody, but Fc-2 could not neutralize the antibody.

\section{Characterization of protease treated ovomucoid fragments}

Three peaks were obtained by the protease

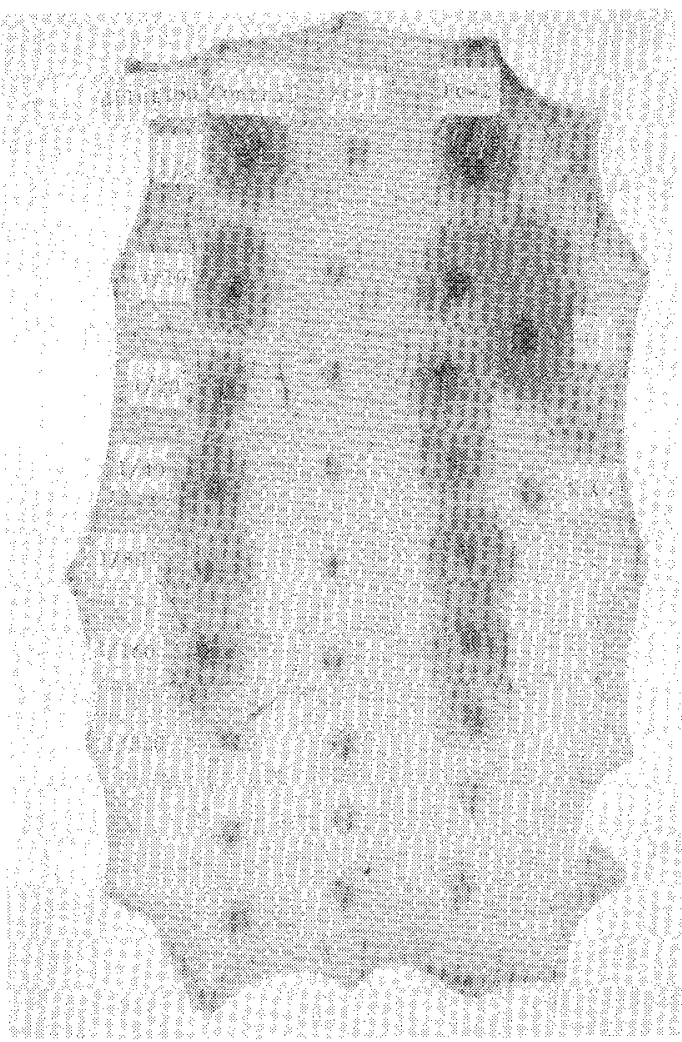

FIG. 3. Profile of PCA Inhibition Test of the Fragments Obtained by Cleavage of Ovomucoid with Cyanogen Bromide.

The antiserum (PCA titer 320) was incubated with a sufficient amount of the fragments at $25^{\circ} \mathrm{C}$ for $1 \mathrm{hr}$. The mixture was diluted five times and further serially twofold. The dilutions $(0.1 \mathrm{ml})$ were injected intracutaneously into the shaved back of an $\mathrm{SD}$ rat. The untreated antiserum and its dilutions were injected to the same animal for control. Two hours later, $1.0 \mathrm{ml}$ of $1 \%$ Evans blue solution containing $3 \mathrm{mg}$ of ovomucoid was injected intravenously. The rat was sacrificed $20 \mathrm{~min}$ later and lesions were measured. A blue spot was regarded as a positive reaction. N.C., negative control; $\mathrm{U}$, undiluted antiserum.

digestion on gel filtration as shown in Fig. 4. Each peak was found to be a single fragment by SDS-urea-polyacrylamide gel electrophoresis as shown in Fig. 5 and was designated $\mathrm{Fv}_{\mathrm{V}}$ 1, $\mathrm{F}_{\mathrm{V}-2}$ and $\mathrm{F}_{\mathrm{V}-3}$ in order of elution. The molecular weights of the three fragments were estimated to be about 20,000 for Fv-1 and 8000 for both Fv-2 and Fv-3 by SDS-ureapolyacrylamide gel electrophoresis.

The carbohydrate composition of protease 
Table II. Titer of the Residual IgE

Antibodies in the Mixture of Antiserum and the Fragments ObTained by

Cyanogen Bromide Cleavage (PCA InHibition Test)

$\begin{gathered}\text { Components added to IgE } \\ \text { antiserum }\end{gathered}$
PCA Titer*
Fone (Control)
Fc-2

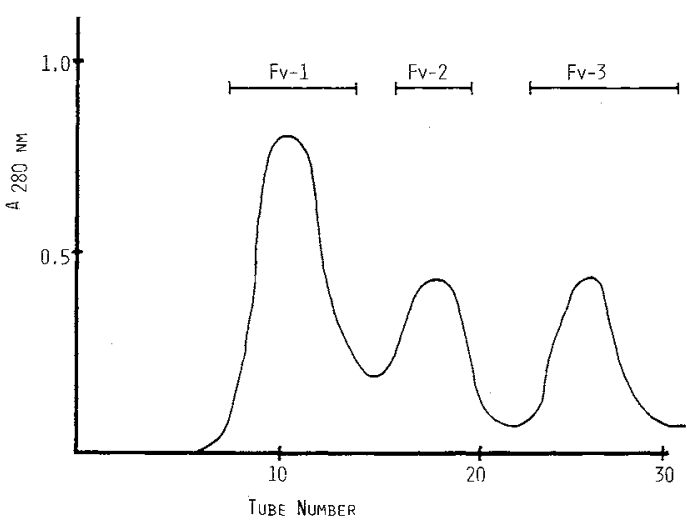

FIG. 4. Gel Filtration Pattern of the Products Obtained by Digestion of Ovomucoid with Staphylococcal Protease.

Conditions of gel filtration were the same as shown in Fig. 1 except that $7 \mathrm{ml}$ of fractions were collected.

treated ovomucoid fragments is summarized in Table III. Sialic acid was neither detected in $\mathrm{Fv}_{\mathrm{V}} 2$ nor in Fv-3. Fv-2 was far richer in glucosamine and hexose than Fv-3. Fv-1 was found to contain glucosamine, hexose and sialic acid. The analyses of amino acid composition and $\mathrm{N}$-terminal residue of each fragment are shown in Table IV. The amino acid compositions of $\mathrm{FV}-2$ and $\mathrm{Fv}-3$ were identical to each other. The $\mathrm{N}$-terminus of $\mathrm{Fv}-1$ was alanine and those of $\mathrm{Fv}-2$ and $\mathrm{Fv}_{\mathrm{V}} 3$ were leucine. $F_{V-1}$ retained the affinity for trypsin, while Fv-2 and Fv-3 did not (Figure not shown).

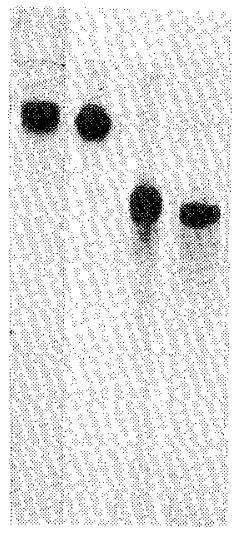

(A) (B) (C) (D)

FIG. 5. SDS-Urea-Polyacrylamide Gel Electrophoretic Profile of the Fragments Obtained by Digestion of Ovomucoid with Staphylococcal Protease.

Electrophoresis was carried out with a current of 2.5 $\mathrm{mA} /$ tube at $\mathrm{pH} 6.8$ using $12.5 \%$ gel containing $8 \mathrm{M}$ urea. $\mathrm{A}$, intact ovomucoid; $\mathrm{B}, \mathrm{Fv}_{\mathrm{V}} 1 ; \mathrm{C}, \mathrm{Fv}_{\mathrm{V}} 2 ; \mathrm{D}, \mathrm{Fv}_{\mathrm{V}} 3$.

\section{Table III. Carbohydrate Composition of the Fragments ObTaINEd By Staphylococcal Protease Digestion}

Results are expressed as mol of residues per mol of peptides

\begin{tabular}{lrrr} 
& Glucosamine & Hexose & Sialic acid \\
\hline Fv-1 & 16 & 11 & 1 \\
Fv-2 & 9 & 2 & 0 \\
Fv-3 & 1 & 1 & 0 \\
\hline
\end{tabular}

\section{PCA inhibitory activity of protease treated ovomucoid fragments}

The titer of the mixture of antiserum and Fv-l was zero as shown in Table V. The result shows that the residual IgE antibodies in the mixture are under the limits which can be detected. Contrarily, in the case of $\mathrm{Fv}_{\mathrm{V}} 2$ and Fv-3, titer were the same (80) as that of the control. Therefore it was concluded that $\mathrm{F}_{\mathrm{V}-1}$ was almost comparable to ovomucoid in binding activity to ovomucoid-specific antibody, but Fv-2 and Fv-3 could not neutralize the antibody. 
TABle IV. Amino Acid Composition AND N-Terminal Residues of the Fragments ObTained by STAPHyLococcal Protease Digestion $(\mathrm{mol} \%)$

\begin{tabular}{lrrrrr}
\hline & Fv-1 & $\begin{array}{c}\text { Peptide* } \\
1 \sim 130\end{array}$ & Fv-2 & Fv-3 & $\begin{array}{c}\text { Peptide* } \\
131 \sim 186\end{array}$ \\
\hline Asp & 15.48 & 16.15 & 16.54 & 15.78 & 16.07 \\
Thr & 7.83 & 7.69 & 7.66 & 7.66 & 7.14 \\
Ser & 5.96 & 5.38 & 8.24 & 8.70 & 8.92 \\
Glu & 8.64 & 8.46 & 7.35 & 6.04 & 7.14 \\
Pro & 2.06 & 2.30 & 5.01 & 4.77 & 5.35 \\
Gly & 7.53 & 8.46 & 8.61 & 8.03 & 5.35 \\
Ala & 5.27 & 5.38 & 7.29 & 7.23 & 7.14 \\
Cys/2 & 8.81 & 9.23 & 7.67 & 10.26 & 10.71 \\
Val & 9.18 & 8.46 & 5.99 & 6.12 & 7.14 \\
Met & 1.42 & 1.53 & 0.00 & 0.00 & 0.00 \\
Ile & 2.22 & 2.30 & 0.00 & 0.00 & 0.00 \\
Leu & 5.64 & 5.38 & 7.09 & 6.76 & 7.14 \\
Tyr & 3.25 & 3.07 & 3.51 & 3.22 & 3.57 \\
Phe & 3.27 & 2.30 & 4.50 & 3.10 & 3.57 \\
Lys & 7.24 & 6.92 & 6.20 & 7.25 & 7.14 \\
His & 2.45 & 3.07 & 2.55 & 2.78 & 1.78 \\
Arg & 3.63 & 3.84 & 2.39 & 2.23 & 1.78 \\
N-Terminus & Ala & Ala & Leu & Leu & Leu \\
\hline & & & & - & - \\
\hline
\end{tabular}

* According to Kato et al. ${ }^{24)}$

\section{DISCUSSION}

The examination of allergenic activity with a large fragments of the allergens is an effective method for the initial step of the localization of the allergenic site. In the present study, the fragmentation of ovomucoid was carried out by using $\mathrm{CNBr}$ and Staphylococcal protease.

In the experiments to cleave ovomucoid with $\mathrm{CNBr}$, ovomucoid was severed into two peptides, i.e. Fc-1 and Fc-2. According to the amino acid sequence reported by Kato et al., ${ }^{24}$ ovomucoid has two methionyl residues at positions 68 and 84. In amino acid composition, the molecular weight and $\mathrm{N}$ terminus, Fc-1 and Fc-2 agreed with the peptides presumed from the selective cleavage at methionine 68 , that is, the peptide $69 \sim 186$ and the peptide $1 \sim 69$ respectively (Table I). Fc- 1 was assumed to be the combination of the peptide $69 \sim 84$ and $85 \sim 186$ with a disulfide bridge because the electrophoretic patterns showed that FC-1 consisted of two polypeptide
Table V. Trter of the Residual IgE Antibodies in the Mixture of ANTISERUM AND the FraGments Obtained by Staphylococcal Protease Digestion (PCA Inhibition TEST)

\begin{tabular}{lc}
$\begin{array}{c}\text { Components added to IgE } \\
\text { antiserum }\end{array}$ & PCA Titer* \\
\hline None (Control) & 80 \\
Fv-1 & 0 \\
Fv-2 & 80 \\
Fv-3 & 80 \\
\hline PCA titer was assayed according to the method of \\
Mota and Wong ${ }^{14)}$ and was expressed as the \\
reciprocal of dilution.
\end{tabular}

chains.

Kato and co-workers reported that ovomucoid was composed of three homologous domains, each containing three intradomain disulfide bridges as shown in Fig. 6. The three domains were termed domain I, II and III in order from the $\mathrm{N}$-terminus. According to the domain structure, $\mathrm{Fc}-2$ corresponds to domain I and Fc-l to the combination of domain II and domain III (Fig. 6).

In the experimets to digest ovomucoid with Staphylococcal protease, three peptides, $\mathrm{FV}_{\mathrm{V}} \mathrm{I}$, Fv-2 and Fv-3 were obtained (Fig. 4). The protease has been reported to cleave ovomucoid between glutamic acid residue at position 130 and leucine 131; therefore, the digests of ovomucoid can be presumed to produce two peptide fragments: the peptide $1 \sim 130$ and $131 \sim 186 .{ }^{24)} \mathrm{FV}_{\mathrm{V}} 1$ was compatible with the peptide $1 \sim 130$ in $\mathrm{N}$-terminus, the molecular weight and the amino acid composition (Table IV). These results indicate that Fv-1 corresponds to the peptide $1 \sim 130$, the combination of domain I and II (Fig. 6). The amino acid composition, $\mathrm{N}$-terminus and the molecular weight of $\mathrm{FV}_{\mathrm{V}} 2$ were identical to those of Fv-3 (Table IV, Fig. 5). Therefore Fv2 and $\mathrm{Fv}_{\mathrm{v}-3}$ were confirmed to have the same amino acid sequence of the peptide $131 \sim 186$, i.e. domain III (Fig. 6). The difference of chromatographic behavior between Fv-2 and $\mathrm{Fv}_{\mathrm{V}-3}$ in gel filtration (Fig. 4) is considered to be due to the difference in the carbohydrate 


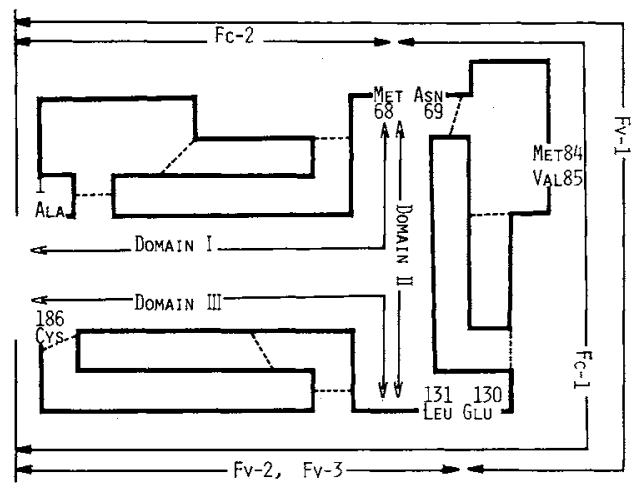

FIG. 6. The Location of the Fragments Obtained by Cyanogen Bromide Cleavage and Staphylococcal Protease Digestion in the Primary Structure of Ovomucoid.

The amino acid sequence of hen's ovomucoid and the regions of the domains refer to the report of Kato et al. ${ }^{24)}$ --- , disulfide bridge; $\rightarrow$, the fragments obtained by cyanogen bromide cleavage and Staphylococcal protease digestion; $\rightarrow$, the regions of the domains.

contents as pointed out by Kato. ${ }^{26)}$

PCA inhibition test was used for examining whether the fragments of ovomucoid had the allergenic determinants which were capable of combining IgE antibody. The combination of domain I and II obtained by the protease digestion was found to maintain PCA inhibitory activity (Table V). The combination of domain II and III obtained by $\mathrm{CNBr}$ treatment, though cleaved at the position 84 and linked together by a disulfide bridge between 70 and 109, also retained PCA inhibitory activity (Table II, Fig. 3). It is suggested that the conformational change caused by the cleavage does not affect the allergenic structure. In a single domain, however, (domain I or III), PCA inhibitory activity was not detected. It was concluded that both the combination of domain I and II and that of domain II and III maintained allergenic activity similar to native ovomucoid. It is of interest that both the fragments with allergenic activity have trypsin binding ability (Fig. 2).

In the light of our results, we should like to propose the following concepts concerning the allergenic determinants of ovomucoid. One is that allergenic activity is exhibited by the presence of two domains or more, for example, the combination of doamin I and II or that of domain II and III. The other is that domain II, which is a common part of Fv-1 and Fc-1, contains most of allergenic determinants. Experiments leading to a more precise localization of the allergenic determinants in ovomucoid are in progress.

Acknowledgment. We are indebted to Dr. Toshiki Morichi in the National Institute of Animal Industry for the supply of eggs.

\section{REFERENCES}

1) F. Perlman, "Immunological Aspects of Foods," ed. by N. Catsimpoolas, Avi Publishing Company Inc., Westport, Conn., 1977, p. 279.

2) M. Miller, B. H. Calif, D. H. Campbell and P. Calif, J. Allergy, 21, 522 (1950).

3) L. Berrens and E. Bleumink, Int. Archs. Allergy, 28, 150 (1965).

4) E. Bleumink and E. Young, Int. Archs. Allergy, 35, 1 (1965).

5) E. Bleumink and E. Young, Int. Archs. Allergy, 40, 72 (1971).

6) T. Mukoyama, E. Iwasaki, M. Baba, S. Kaminogawa, J. Kurisaki, $\mathrm{Y}$. Konishi and $\mathrm{K}$. Yamauchi, unpublished.

7) T. P. King, P. S. Norman and J. T. Connell, Biochemistry, 3, 458 (1964).

8) P. Johnson and D. G. Marsh, Immunochemistry, 3, 91 (1966).

9) S. E. Elsayed, J. Apoid, K. Aas and H. Bennich, Int. Archs Allergy appl. Immun., 52, 59 (1976).

10) S. E. Elsayed and J. Apoid, Int. Archs Allergy appl. Immun., 54, 171 (1977).

11) E. Fredericq and H. F. Deutsch, J. Biol. Chem., 181, 499 (1949).

12) J. G. Beeley and E. Mccairns, Biochim. Biophys. Acta, 271, 204 (1972).

13) N. M. Vaz, J. Phillips-Quagliate, B. Levine and E. Vaz, J. Exp. Med., 134, 1334 (1976).

14) J. Mota and D. Wong, Life Sci., 8, 813 (1969).

15) J. G. Beeley, Biochem. J., 155, 345 (1976).

16) I. Kato, W. J. Kohr and M. Laskowski, Jr., Fed. Proc., 36, 764 (1978).

17) S. Moor and W. H. Stein, "Methods in Enzymology," Vol. 6, ed. by S. P. Colowick, N. O. Kaplan, Academic Press, New York, 1963, p. 819.

18) W. R. Gray, "Methods in Enzymology," Vol. 25, ed. by C. H. W. Hirs, S. N. Timasheff, 1972, p. 129.

19) K. R., Woods and K. T. Wang, Biochim. Biophys. Acta, 133, 369 (1967). 
20) M. Dubois, K. A. Gilles, J. K. Hamilton, P. A. Rebers and F. Smith, Anal. Chem., 28, 350 (1956).

21) L. Warren, J. Biol. Chem., 234, 1971 (1959).

22) K. Weber and M. Osborn, J. Biol. Chem., 244, 4406 (1969).

23) R. T. Swank and K. D. Munkres, Anal. Biochem., 39, 462 (1971).

24) I. Kato, W. J. Kohr and M. Laskowski, Jr., "Regulatory Proteolytic Enzyme and Their Inhibitors," FEBS 11th. meeting, ed. by $\mathrm{S}$.
Magnusson, M. Ottesen, B. Faltmann, K. Danø and H. Neurath, Pergamon Press, Oxford, New York, 1978 , p. 197.

25) I. Kato, J. Schrode, K. A. Wilson and M. Laskowski, Jr., "Proteides of Biological Fluids," Vol. 23, ed. by H. Peeters, Pergamon Press, Oxford, New York, 1977, p. 235.

26) I. Kato, Protein, Nucleic acid and Enzyme, 24, 677 (1979). 